\title{
UJI AKTIVITAS ANTIOKSIDAN EKSTRAK DAUN DAN KULIT LABU AIR (Lagenaria siceraria (Molina) Stand1.)
}

\author{
Antioxidant Activity of Calabash's Leaves and Skin Extract (Lagenaria \\ siceraria (Molina) Standl.)
}

\author{
* Masrifah, Nurdin Rahman dan Paulus H. Abram \\ Pendidikan Kimia/FKIP - Universitas Tadulako, Palu - Indonesia 94118
}

Recieved 08 March 2017, Revised 10 April 2017, Accepted 09 May 2017

\begin{abstract}
The aim of study was to determine the inhibitory concentration $\left(I C_{50}\right)$ of free radicals on extract of calabash's leaves and skins. The sample used in this study was the extract of calabash's leaves and skinsthat made of $100 \mathrm{mg} / \mathrm{L}$ concentration.Determination inhibitory concentration of free radicals after adding DPPH (2,2-diphenyl-1-picrylhydrazyl) on the samples was determined using UV-Vis spectrophotometry. Concentration variations in leaves and skins extract of calabash used was 5, 10, 15 and $20 \mathrm{mg} / L$. The positive control used a vitamin $C$ solution with a concentration that inditical to the concentration of the sample 5, 10,15 and $20 \mathrm{mg} / \mathrm{L}$. In the other hand, the negative control used a DPPH solution that was dissolved in ethanol p.a. The results showed that the leavesand skins extract of calabash with control of vitamin $C$ have a concentration inhibition of free radicals $\left(I C_{50}\right)$ respectively was $9.268 \mathrm{mg} / \mathrm{L}$ (leaf extract), $9.332 \mathrm{mg} / \mathrm{L}$ (skin extract) and $6.839 \mathrm{mg} / \mathrm{L}$ (Vitamin C). The matterit was indicated that leaves and skins extract of casablash wasa powerfully natural antioxidant.
\end{abstract}

Keywords: Antioxidant, calabahs, test antioxidants method with DPPH, free radical.

\section{Pendahuluan}

Radikal bebas merupakan suatu atom, gugus atom atau molekul yang memiliki satu atau lebih elektron yang tidak berpasangan pada orbital paling luar, termasuk diantaranya adalah atom hidrogen, logam-logam transisi dan molekul oksigen. Radikal bebas bersifat tidak stabil karena kehilangan elektronnya. Untuk menjadi stabil, radikal bebas akan mengambil elektron dari molekul atau sel lain dalam tubuh kita. Proses pengambilan elektron dari sel-sel tubuh kita menyebabkan kerusakan sel (Holistic, 2011).

Berbagai penyakit yang telah diteliti dan diduga kuat berkaitan dengan aktivitas radikal bebas yakni mencakup lebih dari 50 penyakit seperti stroke, asma, pankreatitis, radang usus, penyumbatan kronis pembuluh darah di jantung, penyakit parkinson, sel sickle leukimia, artritis rematoid, pendarahan otak, tekanan darah tinggi dan AIDS (Sari, 2012). Radikal bebas tersebut akan mulai menyerang

\section{*Correspondence:}

Masrifah

Program Studi Pendidikan Kimia, Fakultas Keguruan dan Ilmu Pendidikan, Universitas Tadulako

email: Ifhaaa032@gmail.com

Published by Universitas Tadulako 2017 bagian tubuh yang sehat maupun yang tidak sehat sehingga menimbulkan suatu penyakit. Beberapa penelitian mengungkapkan bahwa senyawa yang dapat menghambat radikal bebas adalah antioksidan. Antioksidan dapat diperoleh secara endogen (enzim SOD atau superoksid dismutase) dan eksogen melalui makanan atau suplemen (Mau, dkk., 2002). Beberapa senyawa antioksidan dapat ditemukan pada tanaman, antara lain berasal dari golongan polifenol, vitamin $\mathrm{C}$, vitamin $\mathrm{E}, \beta$-karoten dan flavonoid (Hernani \& Rahardjo, 2005)

Salah satu tanaman yang kaya akan beberapa kandungan fitokimia namun kurang diketahui sebagian besar masyarakat yaitu labu air (Lagenaria siceraria (Molina) Standl.) (Shah, dkk., 2010). Beberapa kandungan fitokimia yang dimaksud adalah kalsium, zat besi, vitamin C, polifenol dan saponin (Robinson, 1995). Menurut Saleh \& Marliana (2011),senyawa metabolit sekunder pada ekstrak kasar etanol dari buah labu air (Lagenaria siceraria (Molina) Standl.) adalah saponin, steroid dan fenol. Riset dan Teknologi Kota Bantul menyatakan bahwa daun dan buah Lagenaria leucantha mengandung saponin dan polifenol (Warintek, 2015). 
Jus atau rebusan daun Lagenaria siceraria (Molina) Standl. dapat digunakan sebagai obat emetic (antimuntah), dapat mengatasi kegundulan dan sakit kepala (Shah, dkk., 2010). Sementara kulit buah labu air (Lagenaria siceraria (Molina) Standl.) dapat membantu menyembuhkan tumor metastatis (MAT) dan rematik, serta air perasannya yang dicampur dengan minyak bunga lalu diteteskan ke telinga, juga dapat menyembuhkan tumor otak (Kusumah, 2007).

Salah satu metode pengukuran peredaman radikal bebas oleh senyawa antioksidan adalah metode dengan menggunakan DPPH (difenil pikrilhidrazil). Metode DPPH merupakan suatu metode pengukuran antioksidan yang sederhana, cepat dan tidak membutuhkan banyak reagen seperti uji lainnya (santin oksidase, metode tiosianat, antioksidan total). Metode ini didasarkan reduksi DPPH terhadap senyawa penghambat radikal bebas DPPH (antioksidan). Reaksi tersebut menyebabkan terjadinya perubahan warna DPPH awal yang dapat diukur menggunakan spektrofotometer sinar tampak pada panjang gelombang $517 \mathrm{~nm}$ dengan demikian aktivitas peredaman radikal bebas oleh sampel dapat ditentukan (Mailandari, 2012). Aktivitas tersebut dinyatakan sebagai konsentrasi inhibisi (Inhibition Concentration) atau $\mathrm{IC}_{50}$ (Shivapprasad, dkk., 2005). Tulisan ini dimaksudkan untuk menentukan besar konsentrasi inhibisi $\left(\mathrm{IC}_{50}\right.$ ) radikal bebas pada ekstrak daun dan kulit labu air Lagenaria siceraria (Molina) Standl.).

\section{Metode \\ Alat dan Bahan}

Alat-alat yang digunakan dalam penelitian ini yaitu pisau, oven, blender, ayakan 10 mesh, spatula, batang pengaduk, neraca analitik, gelas kimia, gelas ukur, serangkaian alat soxhlet (Gerhadrt SE-412), kertas saring, rotary evaporator (EYELA SB-1100), labu ukur, pipet tetes, pipet ukur, rak dan tabung reaksi, aluminium foil, Spectrophotometer UV-Vis T80+ PG Intruments Ltd.

Bahan yang digunakan dalam penelitian ini yaitu daun dan kulit labu air (Lagenaria siceraria (Molina) Standl.), padatan DPPH (2,2-difenil1-pikrilhidrazil) (A ALDRICH), Vitamin C (Merck) dan etanol p.a. (J.T. BAKER).

\section{Prosedur penelitian}

Preparasi Sampel

Tahap ini diawali dengan mengumpulkan daun dan kulit buah labu air (Lagenaria siceraria (Molina) Standl.)yang muda dan segar.
Selanjutnya sampel dicuci dengan air mengalir hingga tidak ada pengotor yang ikut menempel pada bahan simplisia tersebut. Setelah bersih, kedua sampel dipotong kecil-kecil dan dikeringanginkan selama 1 x 24 jam pada suhu ruang. Setelah kadar air pada sampel berkurang selama 1 hari, kemudian proses pengeringan dilanjutkan dengan pengovenan sampel pada suhu $48^{\circ} \mathrm{C}$ selama \pm 3 hari. Selanjutnya kedua sampel yang telah kering, dihaluskan dengan menggunakan blender. Proses ini dilanjutkan dengan pengayakkan menggunakan ayakan 10 mesh sehingga diperoleh simplisia dalam bentuk bubuk (Nurmillah, 2009).

\section{Ekstraksi Daun dan Kulit Labu Air (Lagenaria siceraria (Molina) Standl.)}

Tahap kedua pada penelitian ini adalah proses ekstraksi. Sampel daun dan kulit labu air (Lagenaria siceraria (Molina) Standl.) yang telah halus kemudian ditimbang masing-masing sebanyak 25 gram dengan menggunakan neraca analitik. Setelah itu sampel dibungkus dengan kapas dan kertas saring, kemudian dimasukkan ke dalam thimbel (selongsong tempat sampel pada alat soxhlet). Pelarut yang digunakan yaitu etanol p.a. sebanyak 250 $\mathrm{mL}$ yang kemudian dimasukkan ke dalam labu alas bulat(Kadji, dkk., 2015). Ekstraksi dilakukan secara berulang-ulang hingga diperoleh larutan simplisia (pada timbel) berubah bening. Ekstrak-etanol yang diperoleh dari hasil soxhletasi kemudian dievaporasi dengan menggunakan rotary evaporator pada suhu $45^{\circ} \mathrm{C}$ hingga diperoleh ekstrak kental (Mayakrishnan, dkk., 2013).

Pembuatan Larutan DPPH (2,2-difenil-1pikrilhidrazil):

$1,25 \mathrm{mg}$ padatan DPPH ditimbang, kemudian dilarutkan dengan etanol p.a.secukupnya dan dimasukkan ke dalam labu ukur $25 \mathrm{~mL}$ lalu dicukupkan volumenya dengan etanol p.a. hingga tanda batas kemudian dihomogenkan.

\section{Pembuatan Larutan Blanko:}

1,0 mL etanol p.a. dimasukkan ke dalam tabung reaksi kemudian ditambahkan dengan 1,0 mL larutan DPPH dan 2,0 mL etanol p.a. lalu dihomogenkan.

Pembuatan Larutan Induk Ekstrak (konsentrasi $100 \mathrm{mg} / \mathrm{L})$ :

2,5 mg ekstrak sampelditimbang, kemudian dilarutkan dengan etanol p.a. secukupnya lalu dimasukkan ke dalam labu ukur $25 \mathrm{~mL}$ dan 
dicukupkan volumenya hingga tanda batas kemudian dihomogenkan.

Pembuatan Larutan Uji dengan Konsentrasi 5 $\mathrm{mg} / \mathrm{L}, 10 \mathrm{mg} / \mathrm{L}, 15 \mathrm{mg} / \mathrm{L}$ dan $20 \mathrm{mg} / \mathrm{L}$ :

Larutan induk diambil 1,25, 2,5, 3,75 dan 5 $\mathrm{mL}$ dengan menggunakan pipet ukur kemudian dimasukkan ke dalam masing-masing labu ukur $25 \mathrm{~mL}$ dan dicukupkan volume larutan tersebut dengan etanol p.a. hingga tanda batas lalu dihomogenkan.

Setelah itu, masing-masing larutan tersebut diambil sebanyak 1,0 mL dan dimasukkan ke dalam masing-masing tabung reaksi kemudian ke dalam masing-masing tabung reaksi tersebut ditambahkan 1,0 ml DPPH dan $2 \mathrm{~mL}$ etanol p.a. lalu dihomogenkan.

Pembuatan Larutan Induk Kontrol Vitamin C (100 mg/L) Sebagai Pembanding :

2,5 mg vitamin $\mathrm{C}$ ditimbang dan dilarutkan dengan etanol p.a. secukupnya lalu dimasukkan ke dalam labu ukur $25 \mathrm{~mL}$ dan dicukupkan volumenya hingga tanda batas kemudian dihomogenkan.

Pembuatan Larutan Seri Vitamin C Konsentrasi $5 \mathrm{mg} / \mathrm{L}, 10 \mathrm{mg} / \mathrm{L}, 15 \mathrm{mg} / \mathrm{L}$ dan $20 \mathrm{mg} / \mathrm{L}$ :

Larutan induk diambil $1,25,2,5,3,75$ dan $5 \mathrm{~mL}$ dengan menggunakan pipet ukur kemudian dimasukkan ke dalam masingmasing labu ukur $25 \mathrm{~mL}$ dan dicukupkan volume larutan tersebut dengan etanol p.a. hingga tanda batas lalu dihomogenkan. Selanjutnya, masing-masing larutan tersebut diambil sebanyak 1,0 mL dan dimasukkan ke dalam masing-masing tabung reaksi kemudian ke dalam masing-masing tabung reaksi tersebut ditambahkan 1,0 ml DPPH dan $2 \mathrm{~mL}$ etanol p.a. lalu dihomogenkan.

Larutan blanko, larutan uji dan larutan kontrol vitamin C diinkubasi pada suhu ruang dan kondisi gelap selama 30 menit. Selanjutnya absorbansi dari masing-masing larutan tersebut diukur dengan menggunakan Spectrophotometer UV-Vis $\quad \mathrm{T}^{80^{+}} \quad \mathrm{PG}$ Instruments Ltd pada panjang gelombang $(\lambda)$ yaitu $517 \mathrm{~nm}$.Data absorbansi yang diperoleh pada pengukuran di atas, selanjutnya digunakan untuk menghitung nilai $\mathrm{IC}_{50}(\mathrm{ppm})$.

\section{Hasil dan Pembahasan}

Pengujian aktivitas antioksidan ekstrak daun dan kulit buah labu air (Lagenaria siceraria (Molina) Standl.) dilakukan dengan tahap awal yaitu proses ekstraksi dengan tujuan untuk menarik senyawa aktif antioksidan yang terdapat di dalam bahan uji. Simplisia yang diekstraksi mengandung beberapa senyawa antioksidan seperti polifenol, saponin dan vitamin C (Robinson, 1995). Ekstraksi senyawa antioksidan dari daun dan kulit buah labu air (Lagenaria siceraria (Molina) Standl.) dilakukan dengan metode soxhletasi menggunakan pelarut etanol p.a. dengan perbandingan $1: 10(25 \mathrm{~g}$ sampel-250 $\mathrm{mL}$ pelarut). Dari perbandingan tersebut diharapkan dengan jumlah pelarut yang 10 kali lebih banyak dari sampel dapat menarik komponen zat aktif dengan cukup besar. Pemilihan pelarut harus didasarkan pada sifat polaritas, stabilitas dan harga. Etanol dipilih karena bersifat polar, tidak toksik, murah, mudah diperoleh serta memiliki tranparansi yang cukup tinggi yaitu $220 \mathrm{~nm}$ (Day \& Underwood, 2001). Berdasarkan perhitungan persen rendemen hasil ekstrak sampel daun dan kulit labu air (Lagenaria siceraria (Molina) Standl.) maka diperoleh rendemen masingmasing sampel yang disajikan pada Tabel 1 .

Tabel 1. Persen Rendemen Ekstrak Daun dan Kulit Labu Air (Lagenaria siceraria (Molina)

$$
\text { Standl.) }
$$

\begin{tabular}{ccccc}
\hline No & Jenis Sampel & $\begin{array}{c}\text { Bobot Sampel } \\
\text { Kering }(\mathrm{g})\end{array}$ & $\begin{array}{c}\text { Bobot Ekstrak } \\
(\mathrm{g})\end{array}$ & $\begin{array}{c}\text { Rendemen } \\
(\%)\end{array}$ \\
\hline 1 & Daun & 25 & 22,64 & 90,56 \\
2 & Kulit Buah & 25 & 24,13 & 96,52 \\
\hline
\end{tabular}

Uji Aktivitas Antioksidan Ekstrak Daun dan Kulit ( Lagenaria siceraria (Molina) Standl.)

Metode yang digunakan dalam pengujian antioksidan ini yaitu metode dengan DPPH (2,2-difenil-1-pikrilhidrazil). Uji ini memerlukan larutan DPPH sebagai reagen penguji terhadap sampel yang diduga mengandung senyawa aktif antioksidan. Metode ini adalah metode yang paling sering digunakan untuk skrining aktivitas antioksidan berbagai tanaman obat (Shivapprasad, dkk., 2005). Hal ini dikarenakan dalam pengujiannya yang sederhana, cepat dan tidak membutuhkan banyak reagen seperti uji lainnya (santin oksidase, metode Tiosianat, antioksidan total) (Mailandari, 2012).

Ekstrak daun dan kulit labu air (Lagenaria siceraria (Molina) Standl.) yang telah diperoleh sebelumnya dibuat dalam bentuk larutan dengan beberapa variasi konsentrasi $(5,10$, 15 dan $20 \mathrm{mg} / \mathrm{L}$ ) lalu direaksikan dengan larutan DPPH (2,2-difenil-1-pikrilhidrazil). Larutan uji dengan variasi konsentrasi tersebut kemudian diinkubasi dalam kondisi gelap, pada suhu ruang selama 30 menit (Molyneux, 2004). Absorbansi dari sampel kemudian diukur dengan menggunakan Spectrophotometer 
UV-Vis pada panjang gelombang 517 nm(Mayakrishnan, dkk., 2013), sehingga diperoleh grafik hubungan absorbansi terhadap konsentrasi seperti yang terlihat pada Gambar 1 .

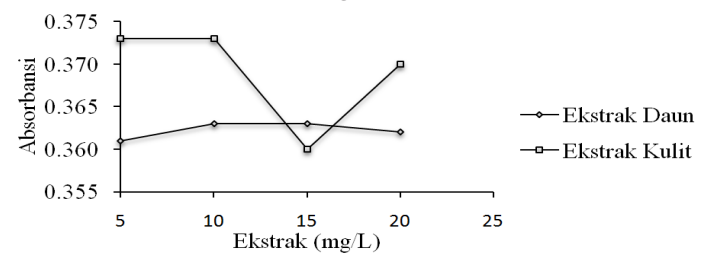

Gambar 1. Grafik Absorbansi Ekstrak Daun dan Kulit Labu Air (Lagenaria siceraria (Molina) Standl.)

Berdasarkan Gambar 1 dapat dilihat bahwa nilai absorbansi ekstrak daun labu air (Lagenariasiceraria (Molina) Standl.) tidak stabil perubahannya, dimana grafik terlihat naik-turun dengan semakin meningkatnya konsentrasi. Ketidakstabilan absorbansi yang diperoleh tersebut dapat dimungkinkan karena rentang variasi konsentrasi yang dipilih tidak begitu signifikan sehingga hasil serapan yang diperolehpun hampir terlihat seperti berada pada tingkatan yang sama. Hasil absorbansi ini tidak sesuai dengan hukum Lambert-Beer yang menyatakan semakin tinggi konsentrasi maka semakin tinggi pula nilai absorbansi suatu sampel (Kristianingrum, 2010). Hal ini dikarenakan pada pengujian aktivitas antioksidan, sampel uji yang direaksikan dengan senyawa radikal bebas harus mengalami penurunan konsentrasi serapan. Artinya dengan semakin meningkatnya konsentrasi sampel yang kemudian ditambahkan dengan pereaksi radikal bebas tersebut, maka diharapkan nilai serapan yang dihasilkan semakin menurun. Penurunan serapan tersebut menandakan bahwa sampel yang diduga mengandung senyawa aktif antioksidan tersebut, mampu menunjukkan perannya dalam mengoksidasi senyawa radikal bebas tersebut. Kondisi ini dapat dilihat dari perubahan warna dasar radikal DPPH (ungu) menjadi semakin berkurang dengan meningkatnya deret konsentrasi sampel (Shivapprasad, dkk., 2005). Aktivitas antioksidan penangkap radikal dapat diketahui melalui penurunan serapan sampel (Oke \& Hambuger, 2002).

Perbedaan serapan setiap deret konsentrasi sampel yang tidak terlalu jauh dari warna DPPH awal dan warna larutan sampel antara konsentasi sampel yang satu dan lainnya juga hanya sedikit terjadi perbedaan kepekatan warna ungu (warna DPPH) dikarenakan kemampuan mengoksidasi senyawa aktif antioksidan terhadap radikal bebas untuk larutan sampel dari $5 \mathrm{mg} / \mathrm{L}$ sampai $20 \mathrm{mg} / \mathrm{L}$ dengan rentang 5 tidak begitu berbeda. Begitu pula dengan sampel kulit labu air (Lagenaria siceraria (Molina) Standl.), dimana absorbansi setiap deret konsentrasi tidak menunjukkan perbedaan serapan yang signifikan.

Reaksi peredaman radikal bebas oleh senyawa antioksidan dapat dilihat pada Gambar 2.

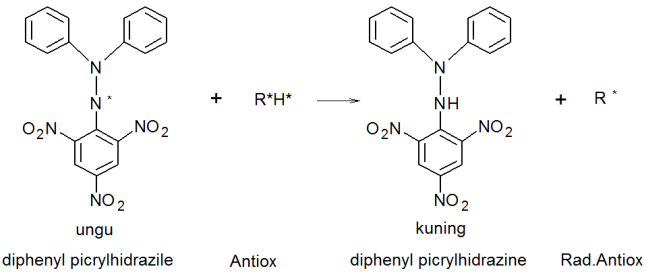

Gambar 2. Reaksi reduksi DPPH dari senyawa peredam radikal bebas (antioksidan) (Mailandari, 2012).

Senyawa antioksidan akan melepaskan atom $\mathrm{H}^{\bullet}$. $\mathrm{H}^{\bullet}$ adalah atom hidrogen yang mengandung satu proton dan satu elektron yang merupakan contoh sederhana dari radikal bebas dan dalam hal ini berasal dari senyawa antioksidan. Terjadinya reaksi DPPH dengan atom $\mathrm{H}^{\bullet}$ menyebabkan radikal bebas DPPH (diphenyl picryrilhidrazil) diubah menjadi diphenyl picryrilhidrazine yang stabil. Sebaliknya, peredaman radikal bebas atau antioksidan yang kehilangan $\mathrm{H}^{\bullet}$ menjadi radikal baru yang lebih stabil dibandingkan radikal DPPH. Radikal antioksidan $\left(\mathrm{R}^{*}\right)$ yang terbentuk pada reaksi tersebut relatif stabil dan tidak mempunyai cukup energi untuk dapat bereaksi dengan molekul lain membentuk radikal baru. Radikal-radikal antioksidan dapat saling bereaksi membentuk produk non radikal. Suatu senyawa dapat digunakan sebagai peredam radikal bebas yang bermanfaat apabila setelah bereaksi dengan radikal bebas akan menghasilkan radikal baru yang stabil atau senyawa bukan radikal (Gordon, 1990).

Selanjutnya dari nilai absorbansi sampel dapat diperoleh persen penghambatan radikal bebas (\% Inhibisi). Persen penghambatan radikal bebas ekstrak daun dan kulit labu air (Lagenaria siceraria (Molina) Standl.) dapat dilihat pada Gambar 3.

Berdasarkan Gambar 3 dengan merujuk pada nilai absorbansi kedua sampel yang telah diperoleh sebelumnya, maka persen penghambatanpun tidak akan jauh berbeda perubahannya dari setiap deret konsentrasi sampel $(5,10,15$ dan $20 \mathrm{mg} / \mathrm{L})$. Aktivitas penghambatan radikal ditandai 


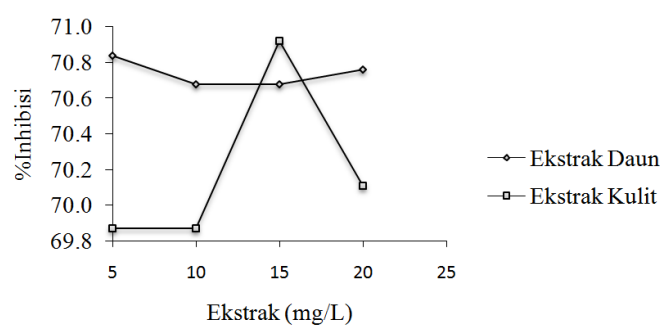

Gambar 3.Grafik \% Penghambatan Radikal Bebas Ekstrak Daun dan Kulit Labu Air (Lagenaria siceraria (Molina) Standl.)

dengan meningkatnya konsentrasi sampel (Mayakrishnan, dkk., 2013). Jadi semakin tinggi konsentrasi, maka persen penghambatanpun akan semakin tinggi, artinya semakin tinggi konsentrasi dengan kandungan senyawa aktif antioksidan lebih banyak, maka kemampuan penghambatan radikal bebasnya akan semakin meningkat pula sehingga menandakan persen inhibisi yang tinggi pada konsentrasi optimum tersebut. Namun hal tersebut tumpang tindih dengan hasil yang ada dimana pada sampel daun (Lagenaria siceraria (Molina) Standl.), larutan $5 \mathrm{mg} / \mathrm{L}$ yang memiliki persen tertinggi $(70,84 \%)$ dibanding larutan konsentrasi $20 \mathrm{mg} / \mathrm{L}(70,76 \%)$. Penurunan \% inhibisi dimungkinkan karena senyawa antioksidan tidak optimal dalam menstabilkan radikal bebas. Kemungkinan yang terjadi adalah senyawatelah bersifat prooksidan. Hal ini sesuai dengan yang dikemukakan Gordon (1990) yang menyatakan bahwa besar konsentrasi antioksidan yang ditambahkan dapat berpengaruh pada laju oksidasi. Pada konsentrasi tinggi, aktivitas antioksidan grup fenolik sering lenyap bahkan antioksidan tersebut menjadi prooksidan. Pengaruh jumlah konsentrasi pada laju oksidasi tergantung pada struktur antioksidan, kondisi dan sampel yang akan diuji (Kadji, dkk., 2015).

Pada sampel kulit labu air (Lagenaria siceraria (Molina) Standl.) hubungan antara konsentrasi dengan persen penghambatan radikal bebas sedikit terlihat lebih baik dari sampel daun labu air (Lagenariasiceraria (Molina) Standl.). Larutan sampel kulit dengan meningkatnya deret konsentrasi juga diikuti dengan naiknya \% inhibisinya (Mayakrishnan, dkk., 2013), dimana pada sampel konsentrasi $5 \mathrm{mg} / \mathrm{L}$ sampai $20 \mathrm{mg} / \mathrm{L}$ cukup mengalami peningkatan persen penghambatan, namun persen penghambatan radikal bebas tertinggi adalah pada konsentrasi $15 \mathrm{mg} / \mathrm{L}(70,92 \%)$ dan sedikit lebih turun pada konsentrasi $20 \mathrm{mg} / \mathrm{L}$ yaitu $70,11 \%$. Hal ini menjelaskan bahwa sampel kulit sedikit menunjukkan aktivitas antioksidan yang sedikit lebih tinggi dibandingkan dengan sampel daun.

\section{Uji Aktivitas Antioksidan Vitamin C}

Larutan kontrol vitamin $C$ pada penelitian ini dibuat dengan deret konsentrasi yang sama dengan konsentrasi sampel yaitu 5, 10, 15 dan $20(\mathrm{mg} / \mathrm{L})$. Hal ini bertujuan agar dapat dibandingkan secara langsung dengan sampel. Adapun hasil pengukuran absorbansidarilarutan vitamin $\mathrm{C}$ yaitu dapat dilihat pada Gambar 4.

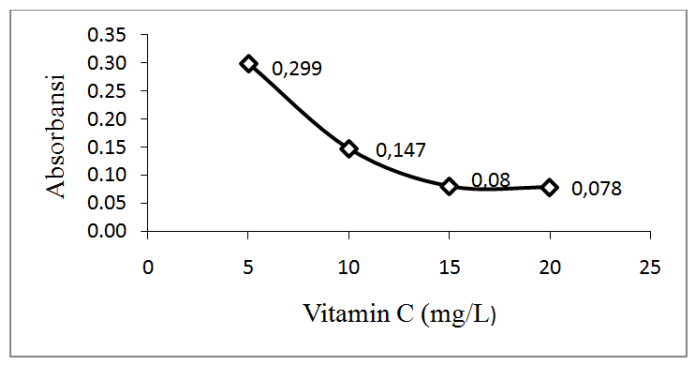

Gambar 4.Grafik Absorbansi Kontrol Vitamin C

Berdasarkan Gambar 4 dapat dilihat dengan jelas penurunan serapan dengan meningkatnya deret konsentrasi, artinya adalah dari konsentrasi terkecil $5 \mathrm{mg} / \mathrm{L}$ menuju ke konsentrasi tertinggi yaitu $20 \mathrm{mg} / \mathrm{L}$ terlihat bahwa semakin tinggi konsentrasi senyawa antioksidan akan semakin tinggi pula kemampuannya dalam mengoksidasi radikal DPPH (Shivapprasad, dkk., 2005). Pada saat vitamin C direaksikan dengan larutan DPPH, warna larutan berubah dari ungu menjadi kuning sehingga hal inilah yang menjadi alasan semakin menurunnya absorbansi pada setiap konsentrasi. Semakin tinggi deret konsentrasi larutan kontrol vitamin C semakin mudah meneruskan cahaya. Kondisi ini sesuai dengan literatur dimana vitamin $C$ sebagai antioksidan alami mampu mengoksidasi radikal bebas secara maksimal, hal ini ditandai dengan uji positif yaitu berubahnya warna DPPH menjadi kuning. Absorbansi terlihat hampir sama yaitu pada konsentrasi $15 \mathrm{mg} / \mathrm{L}$ dan $20 \mathrm{mg} / \mathrm{L}$. Hasil ini dapat diartikan bahwa kemampuan optimum dari kontrol vitamin C ini berada pada konsentrasi $15 \mathrm{mg} / \mathrm{L}$.

Berdasarkan data absorbansi larutan kontrol vitamin $\mathrm{C}$ dapat digunakan untuk menghitung persen penghambatan radikal bebasnya. Persen penghambatan larutan kontrol vitamin Ckonsentrasi $5 \mathrm{mg} / \mathrm{L}, 10 \mathrm{mg} / \mathrm{L}, 15 \mathrm{mg} / \mathrm{L}$ dan $20 \mathrm{mg} / \mathrm{L}$ dapat dilihat pada Gambar 5 .

Berdasarkan grafik tersebut persen penghambatan radikal bebas semakin tinggi dengan meningkatnya konsentrasi. Persen penghambatan terendah dengan konsentrasi 


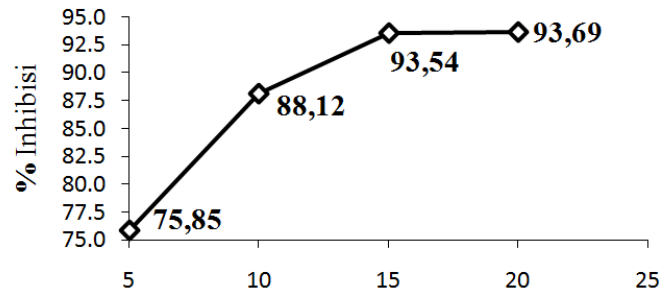

Gambar 5. Grafik Persen Penghambatan Radikal Bebas Vitamin C

$5 \mathrm{mg} / \mathrm{L}$ yaitu $75,85 \%$ dan mencapai $93,69 \%$ pada konsentrasi $20 \mathrm{mg} / \mathrm{L}$. Artinya, semakin tinggi konsentrasi aktivitas antioksidan vitamin C dalam menangkal radikal bebas semakin kuat pula. Hal ini dapat terjadi, karena vitamin $\mathrm{C}$ merupakan senyawa antioksidan alami dalam bentuk murni sehingga aktivitas antioksidannya sangat kuat dalam meredam radikal bebas DPPH dengan \% inhibisi hampir mencapai $100 \%$. Vitamin C termasuk golongan antioksidan sekunder yang mampu menangkal berbagai radikal bebas ekstraseluler. Hal itu dikarenakan vitamin $\mathrm{C}$ mempunyai gugus hidroksi bebas yang bertindak sebagai penangkap radikal bebas dan jika mempunyai polihidroksi akan meningkatkan aktivitas antioksidan (Isnidar \& Setyowati, 2011).

Perbandingan Aktivitas Peredaman RadikalBebas Ekstrak Daun dan Kulit Labu Air (Lagenaria siceraria (Molina) Standl.) Serta Vitamin C

Pada pembahasan sebelumnya telah dihitung data hasil persentase penghambatan sampel daun dan kulit labu air (Lagenaria siceraria (Molina) Standl.) serta vitamin C, sehingga dari persentase kedua sampel dan kontrol postif tersebut dapat dibandingkan persen penghambatannya. Perbandingan ketiga bahan uji tersebut dapat dilihat pada histogram Gambar 6 .

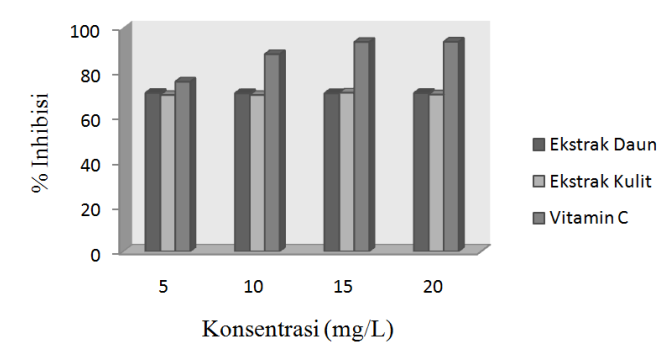

Gambar 6. Grafik Perbandingan Persen Penghambatan Ekstrak Daun dan Kulit Labu Air (Lagenaria siceraria (Molina) Standl.) dengan Vitamin C
Berdasarkan grafik pada Gambar 6 di atas dapat dilihat bahwa aktivitas penghambatan radikal bebas oleh sampel daun dan kulit labu air (Lagenaria siceraria (Molina) Standl.) cukup mendekati kemampuan vitamin $\mathrm{C}$ sebagai kontrol positif dalam menghambat radikal bebas. Hal ini membuktikan bahwa sampel daun dan kulit labu air (Lagenaria siceraria (Molina) Standl.) dengan konsentrasi yang sama dengan vitamin $\mathrm{C}$ mampu untuk menghambat senyawa radikal bebas dengan cukup kuat. Kedua sampel ini tentunya memiliki kemampuan tersebut dikarenakan pada kedua sampel tersebut mengandung beberapa senyawa aktif antioksidan diantaranya vitamin C, vitamin E, polifenol dan saponin(Shah, dkk., 2010). Akan tetapi banyaknya kandungan antioksidan tersebut belum dapat menjadi pemicu sampel daun dan kulit (Lagenaria siceraria (Molina) Standl.) untuk bisa setara dengan kemampuan vitamin $\mathrm{C}$ murni sebagai kontrol positif. Beberapa penyebabnya bisa dipengaruhi karena lama waktu pemanasan ataupun kesalahan paralaks yang dapat disebabkan kondisi alat (lampu Spectrophotometer UV-Vis) yang kurang baik serta kesalahan yang bisa muncul pada saat pembuatan deret konsentrasi.

Perbandingan sampel daun dan kulit labu air jika ditinjau dari diagram batang Gambar 6 tersebut, terlihat tidak menunjukkan perbedaan yang signifikan menyangkut kemampuan aktivitas antioksidan antara sampel daun dan kulit (Lagenaria siceraria (Molina) Standl.). Namun untuk menginterpretasikan data ini lebih lanjut, maka perlu dilakukan suatu perhitungan $\mathrm{IC}_{50}$ untuk dapat menggolongkan tingkat kemampuan kedua sampel ini dalam menghambat radikal bebas (DPPH) (Molyneux, 2004).

\section{Konsentrasi Penghambatan $\left(I C_{50}\right)$}

Nilai $\mathrm{IC}_{50}$ dapat diperoleh dengan memplotkan nilai probit sebagai variabel Y dan deret konsentrasi yang dilogkan sebagai variabel X sehingga diperoleh suatu persamaan regresi linear. Nilai $x$ pada persamaan regresi linear dari suatu grafik digunakan untuk menetukan nilai $\mathrm{IC}_{50}$ dalam suatu konsentrasi ppm dan sejenisnya. Nilai $\mathrm{x}$ akan diperoleh setelahmengganti nilai $Y=5$ (probit dari 50\%), lalu kemudian nilai log konsentrasi yang diperoleh tersebut dikonversi ke bentuk anti log sehingga diperoleh nilai $\mathrm{IC}_{50}$ dalam konsentrasi ppm(Pratiwi, dkk., 2014). Grafikyang diperoleh untuk sampel daun labu air (Lagenaria siceraria (Molina) Standl), sampel kulit air (Lagenaria siceraria (Molina) Standl.) dan kontrol 
vitamin C dapat dilihat pada Gambar 7-9.

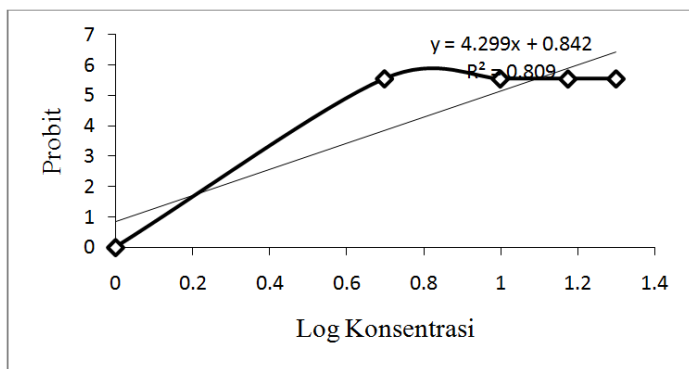

Gambar 7. Hubungan Log Konsentrasi dan Probit Ekstrak Daun Labu Air (Lagenaria siceraria (Molina) Standl.)

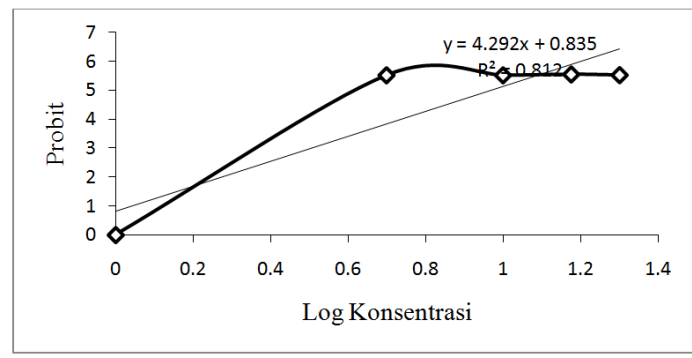

Gambar 8. Hubungan Log Konsentrasi dan Probit Kulit Labu Air (Lagenaria siceraria (Molina) Standl.)

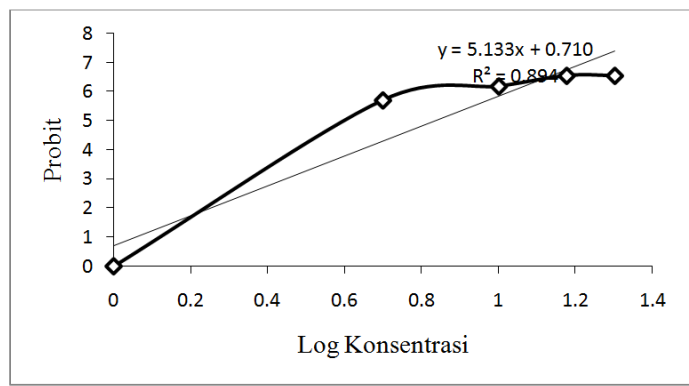

Gambar 9. Hubungan Log Konsentrasi dan Probit Vitamin C

Berdasarkan Gambar 7-9 secara berturutturut diperoleh persaman regresi linear yaitu $\mathrm{Y}=4,2993 \mathrm{X}+0,8428$ (sampel daun labu air (Lagenaria siceraria (Molina) Standl.), $\mathrm{Y}=4,2929 \mathrm{X}+0,8354$ (sampel kulit labu air Lagenaria siceraria (Molina) Standl.) dan $\mathrm{Y}=$ $5,1337 \mathrm{X}+0,7104$ (kontrol vitamin C) dengan nilai koefisien korelasi atau $\mathrm{r} 2$ untuk masingmasing sampel yaitu $0,8097,0,8120$ dan 0,8947 . Nilai r2 (koefisien korelasi) menunjukkan adanya hubungan linearitas antara probit dan $\log$ konsentrasi. Berdasarkan literatur, nilai r2 yang mendekati 1 menandakan data yang diperoleh sangat baik(Hastono \& Sabri, 2011). Nilai hasil $r 2$ setiap sampel yang memiliki nilai r2 rata-rata adalah 0,80 dan sesuai pula dengan nilai r2 vitamin $C$ sebagai kontrol positif maka apabila dibandingkan dengan literatur tersebut, maka dapat dikatakan hasil ini cukup baik.

Berdasarkan persamaan garis lurus tersebut dapat diperoleh nilai $\mathrm{IC}_{50}$ dari sampel daun dan kulit labu air (Lagenaria siceraria (Molina) Standl.) serta kontrol vitamin C, secara berturut yaitu 9,268 $\mathrm{mg} / \mathrm{L}, 9,332 \mathrm{mg} / \mathrm{L}$ dan kontrol vitamin C 6,839 mg/L. Menurut Molyneux (2004), bahwa semakin kecil nilai $\mathrm{IC}_{50}$ menunjukkan semakin tingginya aktivitas antioksidan. Suatu senyawa dikatakan memiliki aktivitas antioksidan sangat kuat jika nilai $\mathrm{IC}_{50}$ kurang dari $50 \mathrm{ppm}$, antioksidan kuat untuk $\mathrm{IC}_{50}$ bernilai 50-100 ppm, antioksidan sedang jika bernilai $\mathrm{IC}_{50}$ bernilai 100-150 ppm dan antioksidan lemah jika nilai $\mathrm{IC}_{50}$ bernilai $151-200 \mathrm{ppm}$, sedangkan apabila nilai $\mathrm{IC}_{50}$ berada di atas $200 \mathrm{ppm}$ maka aktivitas antioksidannya sangat lemah.

Apabila nilai hasil $\mathrm{IC}_{50}$ pada sampel di atas dikorelasikan dengan literatur yang ada, maka sampel daun dan kulit labu air (Lagenaria siceraria (Molina) Standl.) dapat dikategorikan sebagai antioksidan alami yang tergolong sangat kuat karena memiliki nilai IC $_{50}$ kurang dari $50 \mathrm{ppm}$. Begitu pula dengan kontrol positif vitamin $\mathrm{C}$ juga menunjukkan hasil yang sesuai, dimana vitamin $\mathrm{C}$ atau asam askorbat dalam bentuk murninya mampu mereduksi senyawa radikal bebas (DPPH), hasil ini terbukti dengan nilai $\mathrm{IC}_{50}$ yang diperoleh kurang dari $50 \mathrm{ppm}$ yakni sebesar 6,839 ppm yang menandakan bahwa vitamin $\mathrm{C}$ merupakan jenis antioksidan alami yang sangat kuat dibanding kedua sampel yang diujikan pada penelitian ini (Isnidar \& Setyowati, 2011).

\section{Kesimpulan}

Nilai konsentrasi inhibisi ( $\left.\mathrm{IC}_{50}\right)$ yangdiperoleh dari sampel daun dan kulit labu air (Lagenaria siceraria (Molina) Standl.) secara berturut-turut yaitu 9,268 mg/L dan 9,332 $\mathrm{mg} / \mathrm{L}$. Kedua nilai konsentrasi penghambatan tersebut, kurang dari 50 ppmsehingga kedua sampel dapat digolongkan ke dalam jenis antioksidan alami yang bersifat sangat kuat.

\section{Ucapan Terima Kasih}

Penulis mengucapkan terima kasih sebesarbesarnya kepada semua yang telah membantu dalam penelitian ini, terkhusus kepada laboran Laboratorium Kimia Fakultas Keguruan dan Ilmu Pendidikan Universitas Tadulako serta 
kepada laboran Laboratorium Agroteknologi Fakultas Pertanian Universitas Tadulako.

\section{Referensi}

Day, R. A. \& Underwood, A. L. (2001). Analisis kimia kuantitatif. Edisi keenam. Jakarta: PT Gelora Aksara Pratama.

Gordon, M. H. (1990). The mechanism of antioxidant action in vitro. London: Elsiever Applied Science.

Hastono, S. P. \& Sabri, L. (2011). Statistik kesehatan. Jakarta: Rajawali Pers.

Hernani \& Rahardjo, M. (2005). Tanaman berkhasiat antioksidan. Jakarta: Penebar Swadaya.

Holistic, H. S. (2011). Khasiat fantastis kulit manggis. Jakarta: Grasindo.

Isnidar, W. S. \& Setyowati, E. P. (2011). Isolasi dan identifikasi senyawa antioksidan daun kesemek (diospyros kaki thunb.) dengan metode DPPH (2,2-difenil-1-pikrilhdrazil). Majalah Obat Tradisional, 16(3), 157-164.

Kadji, M. H., Runtuwene, M. R. J. \& Citraningtyas, G. (2015). Uji fitokimia dan aktivitas antioksidan dari ekstrak etanol daun soyogik (saurauia bracteosa DC). Pharmacon, 2(2), 13-17.

Kristianingrum, S. (2010). Spektroskopi ultraviolet dan sinar tampak (spektroskopi UV-Vis) Handout.

Kusumah, I. (2007). Kesehatan islami, panduan diet ala Rasulullah. Jakarta: Qultummedia.

Mailandari, M. (2012). Uji aktivitas antioksidan ekstrak daun garcinia kydia roxb dengan metode DPPH dan identifikasi senyawa kimia fraksi ekstrak yang aktif. (Skripsi), Universitas Indonesia, Depok.

Mau, J. L., Lin, H. C. \& Song, S. F. (2002). Antioxidant properties of several specialty mushrooms. Food Research International, 35, 519-526.

Mayakrishnan, V., Veluswamy, S., Sundaram, K. S., Kannappan \& Abdullah, N. (2013).
Free radical scavenging potential of lagenaria siceraria (molina) standl fruits extract. Asian Pacific Journal of Tropical Medicine, 6(1), 20-26.

Molyneux, P. (2004). The use of the stable free radical diphenyl picrylhydrazyl (DPPH) for estimating antioxidant activity. Journal Science Technology, 26(2), 211-219.

Nurmillah, O. Y. (2009). Kajian aktivitas antioksidan dan antimikroba ekstrak biji, kulit buah, batang dan daun tanaman jarak pagar (jatropha curcas L.). (Skripsi), Institut Teknologi Bandung, Bogor.

Oke, J. M. \& Hambuger, M. O. (2002). Screening of some nigerian medicinal plants for antioxidant activity using 2,2, diphenylpicryl-hydrazyl radical. African Journal of Biomedical Research, 5, 77-79.

Pratiwi, D., Bintang, M. \& Simajuntak, P. (2014). Lelutung tokak (tabernaemontana macrocarpa jack.) sebagai sumber zat bioaktif antioksidan dan antikanker. Jurnal Ilmu Kefarmasian Indonesia, 12(2), 267272.

Robinson, T. (1995). Kandungan kimia organik tumbuhan tingkat tinggi. Bandung: Institut Teknologi Bandung.

Saleh, C. \& Marliana, E. (2011). Uji fitokimia dan aktivitas antibakteri ekstrak kasar etanol, fraksi n-heksan, etil asetat dan metanol dari buah labu air (Lagenaria siceraria (Molina) Standl.). Jurnal Kimia Mulawarman, 8(2), 693-5616.

Sari, I. R. M. (2012). Uji aktivitas antioksidan dari ekstrak jamur pleorotus ostreatus dengan metode DPPH dan identifikasi golongan senyawa kimia dari fraksi teraktif. (Skripsi), Universitas Indonesia, Depok.

Shah, B. N., Seth, A. K. \& Desai, R. V. (2010). Phytopharmacotology prodile of lagenaria siceraria: A review. Asian Journal of Plant Science, 9(3), 152-157.

Shivapprasad, H. N., Mohan, S., Kharya, M. D., Shiradkar, M. R. \& Lakshman, K. (2005). In-vitro models for antioxidant 
activity evaluation: A review. 2016, from http://www.pharmainfo.net/review/vitromodels-antioxidant-activity-evaluationreview.

Valentao, P. E., Fernandens, F., Carvallo, P. B., Andrade, R. M., Seabra, M. L. \& Bastos. (2001). Antioxidant activity of centaurum erythraea infusion evidenced by its superoxide radical scavenging and xanthine oxide inhibitory activity. Journal Agricultural Food Chemistry, 49(7), 3476-3479.

Warintek. (2015). Lagenaria leucantha (duch.) rusby. 2015, from http://www.warintek. ristek.go.id/pangan_kesehatan/tanaman_ obat/depkes/4-057.pdf. 